Available online at GSC Online Press Directory

GSC Biological and Pharmaceutical Sciences

e-ISSN: 2581-3250, CODEN (USA): GBPSC2

Journal homepage: https://www.gsconlinepress.com/journals/gscbps

(RESEARCH ARTICLE)

\title{
Analysis of bioactive compounds from single herbal siddha distillate kadukkai theeneer through GC-MS
}

\author{
Soman Nair Vinayak ${ }^{1 *}$, Karunakaran Thangadurai ${ }^{2}$, Raveendran Gayatri ${ }^{3}$ and Maniyath Kokkamballiyil \\ Anil Sundaresan 4
}

${ }^{1}$ International Research Foundation for Siddha Science (INFOS), Kannu, Kerala, India. 2Department of Maruthuvam, National Institute of Siddha, Chennai 600047, Tamil Nadu, India. ${ }^{3}$ Department of Noinadal, National Institute of Siddha, Chennai 600047, Tamil Nadu, India. ${ }^{4}$ Department of Holistic Medicine, Apollo Clinic, Kannur, Kerala, India.

Publication history: Received on 03 July 2018; revised on 17 July 2018; accepted on 23 July 2018

Article DOI: https://doi.org/10.30574/gscbps.2018.4.2.0058

\begin{abstract}
The distillate formulations in siddha medicine called theeneer is the aqueous dosage form obtained by the effective distillation of herbal parts especially by using traditional apparatus. Terminalia chebula is an exquisite raw drug used in almost all type of siddha drug formulations. The herb is considered as a rejuvenator with its acclaimed antioxidant property. The usage of the drug is prevalent in many distillate preparations. To prepare the distillate from Terminalia chebula and to analyze the bio active compounds for determining its effectiveness as a rejuvenator and antioxidant supplement. The raw drug kadukkai (Terminalia chebula) was processed and distilled with reference to siddha texts and the distillate sample was analyzed through GC-MS. The prepared kadukkai theeneer was colorless with slight typical odor and taste. A total of 12 compounds were spotted in the sample distillate belonging to class of fatty acid esters and volatile siloxanes. Few of the compounds like hexadecanoic acid and pentadecanoic acid has reputed antioxidant property, other still unreported but can be ascertained as they belong to the same class of fatty acids. The study puts forward the possibility of using kadukkai theeneer as a rejuvenator supplement.
\end{abstract}

Keywords: Siddha medicine; Kadukkai theeneer, GC-MS; Anti- Oxidant; Hexadecanoic acid; Pentadecanoic acid

\section{Introduction}

Siddha medicine, which was developed and propounded by ancient supreme spiritual sages called siddhars with a vision of not only establishing a medical science for the health wellbeing, also to implement and guide fundamental ethics in each one for their spiritual enrichment towards reaching their ultimate goal of wisdom. Siddha medicine considers human body as the direct replica of nature. With much praise should be given to the divine, quote "andathil ullathey pindam, pindathil ullathey andam "stated by siddhar sattaimuni. As a fact of substitution any ailments pertaining to human body there is a healing part in nature [1].The materia medica of siddhars describes vast variety of therapeutically acclaimed resources from plant, animal, and mineral kingdom. With an in-depth knowledge in every aspect of natural resources and how it can be transformed to healing elements of medicine, they developed lakhs of formulations under different categories each suiting for specific conditions of the body and the disease.

Theeneer [2] or distillery medicines is one such unique form of medications under the category of 34 common medications (makkal urai) and as the first choice in divine treatment i.e., 12 supreme classes of medications called deva maruthvam [3]. Vast commentations on theeneer/dravagam are attributed to siddhars like agathiyar, nandidevar,

\footnotetext{
${ }^{*}$ Corresponding author

E-mail address: drvinayak.sasv@gmail.com
}

Copyright (C) 2018 Author(s) retain the copyright of this article. This article is published under the terms of the Creative Commons Attribution Liscense 4.0. 
thirumoolar, pulasthyar, bohar, theraiyar, konganavar, yacobe, ramadevar, yugimuni etc. The potency of the distillate depends on the type of formulations and the raw drug used in it. The distillate of individual herbs as termed as" ekamooligai theeneer" (single herbal distillate) to complex polyherbo mineral preparations is mentioned in siddha texts with varying potency and efficacy [4]. Therefore the two extremes of the distillate are selectively chosen according to the need. Single herbal distillates was commonly used on long term basis as rejuvenators, digestives, blood purifiers , tonics and energizing drinks. Compound distillates from aromatic spices, fruits, seeds and rice varieties were popular during olden days of dravidian history [4]

Kadukkai (Table 1), chebulic myrobalan (Terminalia chebula) belonging to family combretaceae is a well acclaimed rejuvenator and liver tonic used in siddha medicine. The raw drug is put to use in various forms from simple decoctions, powders, distillates and up to extracts (eg. kadukkai sathu) each form having its own specified mode of action or activities [5].

Table 1 General description of kadukkai [5, 6]

\begin{tabular}{|c|c|}
\hline Characteristics & Description \\
\hline Colour & $\begin{array}{l}\text { Colour of the fruit rind varies from yellowish brown, uniform brown to light black } \\
\text { owing to the variety and place of origin }\end{array}$ \\
\hline Odour & Characteristic \\
\hline Taste & Astringent, sweet, sour, pungent, bitter. \\
\hline Potency & Hot \\
\hline Division & Sweet \\
\hline \multirow[t]{2}{*}{ Chemical Constituents } & $\begin{array}{l}\text { Myrobalans contain astringent principles, tannin (tannic acid) } 45 \% \text { and a large } \\
\text { amount of gallic acid (1.21\%), chebulagic acid (5\%), ellagic acid, mucilage, a } \\
\text { brownish yellow coloring matter, chebulinic acid (12.5\%) which when heated in } \\
\text { water splits up into tannic and gallic acid. tannins, which on hydrolysis yield } \\
\text { chebulic acid and d-galloyl glucose. }\end{array}$ \\
\hline & $\begin{array}{l}\text { Fruit possesses corilegin, beta D-glucogallin, glucose and sorbitol. Polyphenolic } \\
\text { compounds, triterpene glycosides, terchebulin (ellagi tannin), terchebin, syringic } \\
\text { acid, punicalagin, terflavin A, flavanoids reducing sugars and starch. Terpene } \\
\text { glycosides, arjungenin and arjun glucoside- } 1 \text { have been isolated from the fruit. }\end{array}$ \\
\hline Pharmacological Actions & $\begin{array}{l}\text { Antioxidant, antimicrobial, antifungal, anticancer, antidiabetic, antiulcer, } \\
\text { antiseptic, carminative, cardio protective, digestive, hepato protective, hemetenic, } \\
\text { immuno modulator, styptic }\end{array}$ \\
\hline $\begin{array}{l}\text { Indications in Siddha } \\
\text { Medicine }\end{array}$ & $\begin{array}{l}\text { Athithoolam (obesity), pun (ulcers), kamalai (jaundice), silipatham (filariasis), } \\
\text { diseases of cheek, throat, tongue and male genitalia, Pandu (Anemia), } \\
\text { Moothrakireecharam (Dysuria), Moolam (Hemorrhoids), Thamaraganoi (Cardiac } \\
\text { diseases), kannnoikal (Eye diseases), Aanmaiinmai (impotency), Gunmam (Gastro } \\
\text { intestinal conditions) Megharogam (Sexually transmitted diseases), Kuttam (Skin } \\
\text { diseases) etc. }\end{array}$ \\
\hline
\end{tabular}

Kadukkai theeneer, the distillate from Terminalia chebula, is been traditionally practiced for different conditions like urinary diseases, bilious diseases including jaundice and cardiac ailments. Kadukkai is also one among the ingredient of many compound distillate formulations like thriphala dravagam and sanjeevi theeneer indicated for phlegmatic diseases, cough, cardiac diseases, jaundice etc [7]. Therefore the objective of the present study was to prepare the distillate of Terminalia chebula as per the siddha drug preparation methods and to screen the bio active principles for determining its effectiveness as a rejuvenator and antioxidant supplement.

\section{Material and methods}

\subsection{Material}

Kadukkai (pericarp of mature fruit of Terminalia chebula). 


\subsection{Method of preparation of distillate sample}

The dry fruit of Terminalia chebula were purchased from a reputed country shop and after it was purified by discarding the seeds, washed and sundried. The pericarp was pounded to coarse powder (figure 1). For about $250 \mathrm{~g}$ of powder 10 parts of water were added thoroughly mixed and secured for 3 days which accounts the period of soaking. On the $4^{\text {th }}$ day the entire contents was transferred to a traditional still apparatus for initiating the distillation [8]. The distillate that was collected in another vessel was preserved for analytical studies.

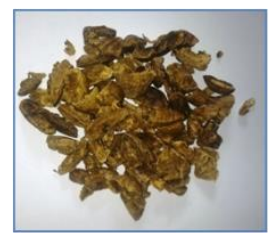

A

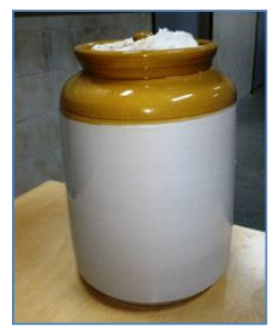

C

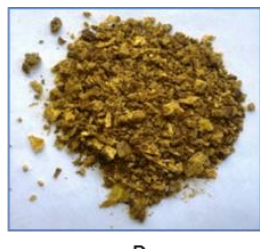

B

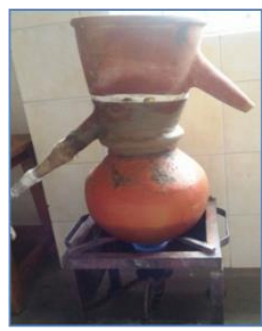

$\mathrm{D}$

Figure 1 Kadukkai (A-Raw, B- Coarse powder, C- Soaking process, D- Traditional vessel for distillation)

\subsection{Gas chromatography- Mass Spectrometry (GC- MS) [9-12]}

GC-MS is a very valuable tool for the analysis of volatile essential oil and compounds, non-polar components, fatty acids and vital alkaloids present in the herbal resources. Gc-ms analysis of the distillate was performed with Agilent 7890b GC connected to 5977A MSD along with NIST ver.2.1 ms data library specification.

\section{Results and discussion}

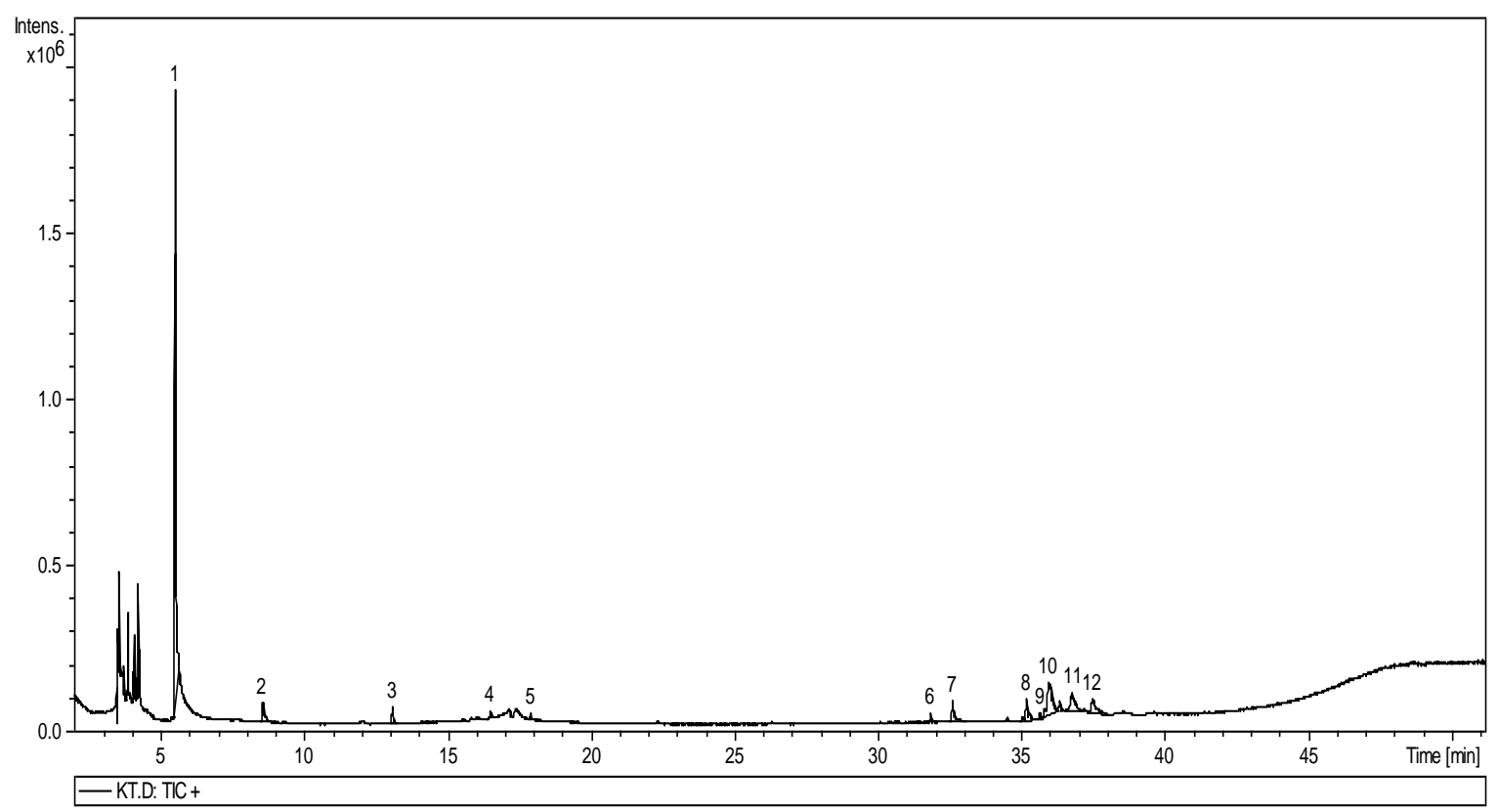

Figure 2 Gas chromatograph of kadukkai theeneer 
The traditional quality parameter of kadukkai theeneer indicates a good standard. The distillate was colorless with peculiar slight odor and taste. The gas chromatogram of kadukkai theeneer revealed 12 prominent peaks with retention time ranging from 5.6 to 37.4. The 12 compounds belong to organic fatty acid group and volatile siloxanes.

GC-MS report of the active compounds with their retention time (RT), peak intensity rank, molecular weight, name, chemical formula and reported pharmacological activities were presented in Figure 2, Table 2 and, 3.

Table 2 Gas chromatograph of kadukkai theeneer

\begin{tabular}{|c|c|c|c|c|c|}
\hline $\begin{array}{l}\text { Peak } \\
\text { no. }\end{array}$ & $\begin{array}{l}\text { Retention } \\
\text { time }\end{array}$ & Name of the compound & $\begin{array}{l}\text { Chemical } \\
\text { formula }\end{array}$ & $\begin{array}{l}\text { Peak intensity } \\
\text { Rank }\end{array}$ & $\begin{array}{l}\text { Molecular } \\
\text { weight }\end{array}$ \\
\hline 1 & 5.6 & Dimethyl Sulfoxide & $\mathrm{C}_{2} \mathrm{H}_{6} \mathrm{OS}$ & 1 & 78 \\
\hline 2 & 8.6 & Cyclotetrasiloxane, octamethyl- & $\mathrm{C}_{8} \mathrm{H}_{24} \mathrm{O}_{4} \mathrm{Si}_{4}$ & 7 & 296 \\
\hline 3 & 13.1 & $\begin{array}{l}\text { Benzoic acid, 2,4-bis [(trimethylsilyl) } \\
\text { oxy]-, trimethylsilyl ester }\end{array}$ & $\mathrm{C}_{16} \mathrm{H}_{30} \mathrm{O}_{4} \mathrm{Si}_{3}$ & 8 & 370 \\
\hline 4 & 165 & $\begin{array}{l}\text { 6-Hydroxymethyl-2,3- } \\
\text { dimethylphenyl methanol }\end{array}$ & $\mathrm{C}_{10} \mathrm{H}_{14} \mathrm{O}_{2}$ & 10 & 166 \\
\hline 5 & 17.9 & Cyclohexasiloxane, dodecamethyl & $\mathrm{C}_{12} \mathrm{H}_{36} \mathrm{O}_{6} \mathrm{Si}_{6}$ & 12 & 444 \\
\hline 6 & 31.8 & $\begin{array}{l}\text { Pentadecanoic acid, 14-methyl-, } \\
\text { methyl ester }\end{array}$ & $\mathrm{C}_{17} \mathrm{H}_{34} \mathrm{O}_{2}$ & 9 & 270 \\
\hline 7 & 32.6 & n-Hexadecanoic acid & $\mathrm{C}_{16} \mathrm{H}_{32} \mathrm{O}_{2}$ & 6 & 256 \\
\hline 8 & 35.1 & 10-Octadecenoic acid, methyl ester & $\mathrm{C}_{19} \mathrm{H}_{36} \mathrm{O}_{2}$ & 5 & 296 \\
\hline 9 & 35.6 & $\begin{array}{lr}\text { Cyclopropanebutanoic acid, 2-[[2-[[2- } \\
\text { [(2-pentylcyclopropyl) } \\
\text { ]cyclopropyl] } & \text { methyl } \\
] \text { cyclopropyl]methyl] -, methyl ester }\end{array}$ & $\mathrm{C}_{25} \mathrm{H}_{42} \mathrm{O}_{2}$ & 11 & 374 \\
\hline 10 & 35.9 & 9,12-Octadecadienoic acid (Z,Z)- & $\mathrm{C}_{18} \mathrm{H}_{32} \mathrm{O}_{2}$ & 2 & 280 \\
\hline 11 & 36.7 & $\begin{array}{l}\text { 7,10-Octadecadienoic acid, methyl } \\
\text { ester }\end{array}$ & $\mathrm{C}_{19} \mathrm{H}_{34} \mathrm{O}_{2}$ & 3 & 294 \\
\hline 12 & 37.4 & 9,12-Octadecadienoic acid (Z,Z)- & $\mathrm{C}_{18} \mathrm{H}_{32} \mathrm{O}_{2}$ & 4 & 280 \\
\hline
\end{tabular}

Table 3 Pharmacological significance of compounds spotted in kadukkai theeneer [13-18]

\begin{tabular}{|c|c|c|}
\hline Compounds & Category & Activity \\
\hline $\begin{array}{l}\text { Cyclohexasiloxane, } \\
\text { dodecamethyl }\end{array}$ & Volatile siloxanes & Antimicrobial \\
\hline Hexadecanoic acid (Palmitic acid) & Fatty acid ester & $\begin{array}{l}\text { Antioxidant, antifibrinolytic and } \\
\text { antimicrobial }\end{array}$ \\
\hline \multirow[t]{2}{*}{$\begin{array}{l}\text { 9,12-octadecadienoic acid (Z,Z) } \\
\text { (Linoleic acid) }\end{array}$} & $\begin{array}{l}\text { Poly unsaturated fatty } \\
\text { acid }\end{array}$ & $\begin{array}{l}\text { Anti anaphylactic, antidyslipedemic, } \\
\text { anticancer, antiarteriosclerotic, }\end{array}$ \\
\hline & & $\begin{array}{ll}\text { antiarthritic, antieczemic, anti } \\
\text { fibrinolytic, antihistaminic, } & \text { and } \\
\text { antiobesity } & \end{array}$ \\
\hline $\begin{array}{l}\text { Pentadecanoicacid } 14 \text {-methyl-, } \\
\text { methyl ester }\end{array}$ & Saturated fatty acid & Antioxidant \\
\hline
\end{tabular}


Oxidative stress as a matter of fact is the consequence of an inequilibrium between free radical production and antioxidant defenses. Many of the lifestyle diseases like cardio vascular diseases, cancers and almost all inflammatory diseases has an underlying cause of oxidative events. The oxidative or free radical damage to healthy cells accelerates the ageing process and also the pathological changes associated with it [19].

Natural anti- oxidants play a key role by delaying or inhibiting such cellular damages by its radical scavenging property. Herbs are good sources of antioxidants and herbal distillates were used as supplements and regular tonics in olden periods for its rejuvinative potential.

Many of the compounds screened from kadukkai theeneer have reputed pharmacological activity while others are still unreported. Volatile siloxanes like cyclotetrasiloxane are present in volatile oils of most of herbs (zhenhs etal). Hexadecanoic acid (palmitic acid) one of an important fatty acid ester has been identified in the distillate has reported antioxidant property [13]. 9, 12-octadecadienoic acid (z, z) (linoleic acid) is a poly unsaturated essential fatty acid (omega- 6 fatty acid) that is very important for human nutrition and cardiovascular health. Pentadecanoic acids also have reported antioxidant activity $[15,16,17]$. We may assume that the other fatty acid esters screened which belongs to the same isomer and fatty acid class too has the same biological property.

\section{Conclusion}

The Gas chromatography studies of siddha herbal distillate kadukkai theeneer reported the presence of many antioxidant compounds and this may further supports its considerable rejuvenator potential and cardio protective effects. The distillate as a regular supplement may benefit for oil aged peoples and cardiac patients.

\section{Compliance with ethical standards}

\section{Acknowledgments}

The authors express their gratitude to Noble Research Solutions, Chennai for all the technical support they have given for this study.

\section{Disclosure of conflict of interest}

We the Authors of this research work, Vinayak S, Thangadurai K. , Gayatri R. and Anil Sundaresan have no conflict of interest and they are solely responsible for all the contents and writings present in this research work.

\section{References}

[1] Sambasivam Pillai TV. (1993). Introduction to Siddha medicine. $3^{\text {rd }}$ Edition. Directorate of Indian medicine and Homeopathy, Chennai, 10.

[2] Anaivari A. (2013). Gunapadam thathu jeeva vaguppu, $8^{\text {th }}$ Edition. Directorate of Indian Medicine \& Homeopathy, Chennai, 70.

[3] Uthamarayan K. (2009). Siddhar Aruvai Maruthvam. 5th Edition, Department of Indian Medicine and Homeopathy, Chennai, 5.

[4] Nair VS, Gayatri R, Sivakumar S, Sivaraman D, Visweswaran S and Banumathi V. (2017). A review on theeneer and dravagam (distillates) used in siddha medicine and their biomedical application in chemistry and healthcare system. International Journal of Medical Research and Pharmaceutical Sciences, 4(3), 32-48.

[5] Murugesa mudhaliyar KS. (2008). Gunapadam-mooligai vaguppu. 2nd edition. Directorate of Indian Medicine and Homeopathy, Chennai, 203.

[6] Surya Prakash DV, Sree Satya N, Sumanjali Avanigadda and Meena Vangalapati. (2012). Pharmacological Review on Terminalia Chebula. International Journal of Research in Pharmaceutical and Biomedical Sciences, 3(2), 679683.

[7] Siddha Formulary of India. (2001). Part 2 (Tamil Version), $1^{\text {st }}$ Edition. Ministry of Health \& Family Welfare, 173182 .

[8] Ramachandran SP. (1996). Yacobe Vaidhya Chinthamani -700, $1^{\text {st }}$ Edition. Thamarai Noolakam, Chennai, 66. 
[9] Andrew M. (2007). Role of advances in chromatographic techniques in photochemistry. Phytochemistry, 68, 2786-2798.

[10] Hans-Joachim Hubschmann. (2015). Handbook of GC-MS: Fundamentals and Applications, Third edition. Wiley VCH Verlag Gmbh and co. John Wiley \& Sons.

[11] Sriram S. (2011). GC-MS study and phytochemical profiling of Mimosa pudica linn. J of Pharm Resch, 4(3), 741742.

[12] Sheeba Gnanadeebam D and Viswanathan P. (2014). GC-MS Analysis of phytocomponents in Spermacoce articularis L. f. leaf. Research in Pharmacy, 4(4), 1-7.

[13] Witkowska- Banaszczak E and Dlugaszewska J. (2017). Essential oils and hydrophilic extracts from leaves and flowers of Succisa pratensis Moench and their biological activity. Journal of Pharmacy and Pharmacology, 69 (11), 1531-1539.

[14] Dhankar S, Kumar M, Ruhil S, Balhara M and Chillar AK. (2012). Analysis toward innovative herbal antibacterial and antifungal drugs. Recent Patents on Anti-Infective Drug Discovery, 7(3), 242-8.

[15] Beppu F, Hosokawa M, Tanaka L, Kohno H, Tanaka T and Miyashita K. (2006). Potent inhibitory effect of Trans 9, Trans 11 isomer of conjugated Linoleic acid on the growth of human colon cancer cells. Journal of Nutritional Biochemistry, 17(12), $830-6$.

[16] Jean-Michel G, Johan H, Kjetil H, Knut K, Han F, Hogne V and Ola G (2004). Conjugated Linoleic acid supplementation for $1 \mathrm{y}$ reduces fat mass in healthy overweight humans. The American Journal of Clinical Nutrition, 79(6), 1118- 1125.

[17] Smedman A and Vessby B. (2001). Conjugated Linoleic acid supplementation in human - metabolic effects. Lipids, 36(8), 773- 81 .

[18] Patel CJ, Satyanand T, Nirmala H, Yadav J, Pathak S, Singh SP, Pandey A, Singh DK and Shankar P. (2013). Antioxidant activity of herbal plants: A recent review. Journal of Drug discovery and Therapeutics, 1(8), 1-8.

[19] Sylvie DD, Anatole PC, Cabral BP and Veronique PB. (2014). Comparison of in vitro antioxidant properties of extracts from three plants used for medical purpose in Cameroon: Acalypha racemosa, Garcinia lucida and Hymenocardia lyrata. Asian Pacific Journal of Tropical Biomedicine, 4, S625-S632.

\section{How to cite this article}

Soman Nair V, Karunakaran T, Raveendran G and Maniyath Kokkamballiyil AS. (2018). Analysis of bioactive compounds from single herbal siddha distillate of kadukkai theeneer through GC-MS. GSC Biological and Pharmaceutical Sciences, $4(2), 31-36$. 